University of Wollongong

Research Online

Faculty of Engineering - Papers (Archive)

Faculty of Engineering and Information

Sciences

$1-1-2009$

\title{
Removal of boron, fluoride and nitrate by electrodialysis in the presence of organic matter
}

Laura J. Banasiak

University of Wollongong, lbanasia@uow.edu.au

Andrea I. Schafer

University of Edinburgh

Follow this and additional works at: https://ro.uow.edu.au/engpapers

Part of the Engineering Commons

https://ro.uow.edu.au/engpapers/568

\section{Recommended Citation}

Banasiak, Laura J. and Schafer, Andrea I.: Removal of boron, fluoride and nitrate by electrodialysis in the presence of organic matter 2009, 101-109.

https://ro.uow.edu.au/engpapers/568

Research Online is the open access institutional repository for the University of Wollongong. For further information contact the UOW Library: research-pubs@uow.edu.au 
1 Removal of boron, fluoride and nitrate by electrodialysis in the presence of organic matter

2

14 Abstract

15 The removal of the trace inorganic contaminants boron $\left(\mathrm{B}(\mathrm{OH})_{4}^{-}\right)$, fluoride $(\mathrm{F})$ and nitrate $\left(\mathrm{NO}_{3}{ }^{-}\right)$

16 from synthetic aqueous solutions containing organic matter using electrodialysis was investigated.

$19 \mathrm{NO}_{3}^{-}$, with the smaller hydrated ionic radius and weaker hydration shell, was removed more

20 effectively than $F$, which has a larger hydrated ionic radius and stronger hydration shell. The

21 removal of $\mathrm{F}^{-}$and $\mathrm{NO}_{3}^{-}$was not significantly influenced by solution $\mathrm{pH}$ due to their $\mathrm{pH}$ independent 
speciation. However, the removal of boron was dependent on increasing solution $\mathrm{pH}$ and the degree of demineralization. Dissolved organic matter (humic acid, tannic acid and alginic acid) resulted in enhanced removal of boron and $F^{-}$as a result of the binding of $F^{-}$within the organic matter structure and complexation of boric acid $\left(\mathrm{B}(\mathrm{OH})_{3}\right)$ with carboxylate groups in the organic matter. Deposition of organic matter to the anion-exchange membranes was noted. Inorganic trace contaminant and organic matter membrane deposition influenced system performance in regards to an increase in stack resistance and decrease in removal and flux of total dissolved solids.

Keywords: Electrodialysis; Ion transport; Inorganic trace contaminant removal; Dissolved organic matter; Fouling; Groundwater/Brackish water

\section{Introduction}

Membrane processes such as electrodialysis (ED) are increasingly being utilised in water treatment to remove dissolved contaminants. A wide range of inorganic trace contaminants, including fluoride $\left(\mathrm{F}^{-}\right)$and nitrate $\left(\mathrm{NO}_{3}{ }^{-}\right)$, can be found in surface, brackish and groundwater. The occurrence and fate of these contaminants is an environmental and public health concern. Concentrations of $\mathrm{F}^{-}$in surface water are relatively low $(<0.1-0.5 \mathrm{mg} / \mathrm{L})$ [1], while concentrations up to $20 \mathrm{mg} / \mathrm{L}$ have been found in groundwater [2]. The harmful effects of excess $\mathrm{F}^{-}$(dental and skeletal fluorosis) have been widely studied $[3,4] . \mathrm{NO}_{3}{ }^{-}$concentrations in surface and groundwater have increased worldwide due to heavy utilization of artificial fertilizers [5]. Deleterious health effects due to $\mathrm{NO}_{3}{ }^{-}$include infantile methemoglobinaemia (known as 'blue-baby' syndrome) and cancer risks for adults and older children [5]. According to the World Health Organization (WHO) [1], the European Union (EU) Drinking Water Directive [6] and the Australian Drinking Water Guidelines (ADWG) [7], the maximum levels for $\mathrm{F}^{-}$and $\mathrm{NO}_{3}{ }^{-}$in drinking water are 1.5 and $50 \mathrm{mg} / \mathrm{L}$, respectively. However, for $\mathrm{NO}_{3}{ }^{-}$a level of $25 \mathrm{mg} / \mathrm{L}$ has been recommended [1, 7]. Due to its high selectivity and low chemical demand, ED has proved an efficient method for desalination and the removal of $\mathrm{F}^{-}$and $\mathrm{NO}_{3}{ }^{-}[8,9]$. 
49 Boron is another contaminant of interest due to its occurrence in seawater and difficulty of removal 50 in desalination. While natural concentrations in surface and groundwaters are usually low, 51 concentrations up to $100 \mathrm{mg} / \mathrm{L}$ have been found as a result of wastewater discharge [10]. Longterm consumption of water and food products with increased boron content results in malfunctioning of cardiac-vascular, nervous, and alimentary systems of humans [11]. The WHO and EU Council have set limits of $0.5 \mathrm{mg} / \mathrm{L}$ and $1 \mathrm{mg} / \mathrm{L}$ for drinking water, respectively [1, 6]. Boron removal using ED has previously been studied [12, 13]; however its interaction with organic matter $(\mathrm{OM})$ and the subsequent impact on its removal has not been investigated. ED is capable of removing $42-75 \%$ of boron, with removal efficiency dependent on solution $\mathrm{pH}(97 \%$ at $\mathrm{pH} 9$ 10) and the degree of desalination $[10,13]$. In acidic and near neutral aqueous environments boron is mainly present as $\mathrm{B}(\mathrm{OH})_{3}$ and partially as borate ions according to the dissociation reaction $(\mathrm{Ka}=$ $6 \times 10^{-10}, \mathrm{pKa} 9.24$ at $\left.25^{\circ} \mathrm{C}\right)[14]:$

$$
\mathrm{B}(\mathrm{OH})_{3}+\mathrm{H}_{2} \mathrm{O} \rightleftharpoons \mathrm{B}(\mathrm{OH})_{4}{ }^{-}+\mathrm{H}^{+}
$$

Organic matter $(\mathrm{OM})$ occurs in aquatic ecosystems in concentrations of 0.5 to $100 \mathrm{mgC} / \mathrm{L}$ [15] and have been a focal point in water treatment research as they are precursors to disinfection byproducts. Dissolved organic substances (e.g. humic substances) act as ligands for metal ions, oxides hydroxides, minerals and organic micropollutants and form water-soluble and water-insoluble complexes [16]. Organic matter comes with seasonal and location (origin) specific characteristics and hence it is important to consider diverse groups such as humics, polyphenols, and polysaccharides.

In ED, organic substances, such as humate, deposit on the ion-exchange membranes and can cause increases in electrical resistance of the membranes [17]. HA in particular has been reported to be 
responsible for fouling in ED which affects salt flux [18-20]. As most OM is negatively charged at neutral $\mathrm{pH}$, deposits form predominantly on the anion exchange membranes. The impact of such deposits on removal of specific contaminants is not well understood. Further, solute-solute interactions (such as complexation) of $\mathrm{OM}$ with inorganic compounds $\left(\mathrm{B}(\mathrm{OH})_{4}{ }^{-}, \mathrm{F}^{-}\right.$and $\mathrm{NO}_{3}{ }^{-}$) has to date not been investigated. As such interactions are likely to affect removal, the main objective of this study was to examine the influence of $\mathrm{pH}$ and three types of $\mathrm{OM}$ on the removal of $\mathrm{B}(\mathrm{OH})_{4}{ }^{-}, \mathrm{F}^{-}$ and $\mathrm{NO}_{3}{ }^{-}$during ED systematically. In order to achieve this goal the project was conducted in five stages, namely (1) mechanisms of inorganics removal (in absence of OM), (2) OM removal, (3) impact of $\mathrm{OM}$ on inorganics removal, (4) inorganic membrane deposit formation, and (5) organic deposit formation.

\section{Materials and Methods}

\subsection{Chemicals and solution preparation}

The feed solution (diluate and concentrate, 4L each) was prepared by dissolving ACS reagent grade $\mathrm{NaCl}(5 \mathrm{~g} / \mathrm{L})$ and $\mathrm{NaHCO}_{3}(84 \mathrm{mg} / \mathrm{L})$ (Fisher Scientific UK), NaF (5 mg/L; total mass $\left.2.1 \mathrm{mmol}\right)$, $\mathrm{NaNO}_{3}(100 \mathrm{mg} / \mathrm{L}$; total mass $57 \mathrm{mmol})$ and $\mathrm{H}_{3} \mathrm{BO}_{3}(10 \mathrm{mg} / \mathrm{L}$; total mass $7.4 \mathrm{mmol})$ (Sigma Aldrich UK) in ultrapure water. The concentrations of $\mathrm{H}_{3} \mathrm{BO}_{3}, \mathrm{~F}^{-}$and $\mathrm{NO}_{3}{ }^{-}$were selected within the range found in brackish waters $[12,21]$. Experiments with an identical concentration of $10 \mathrm{mg} / \mathrm{L}$ for $\mathrm{H}_{3} \mathrm{BO}_{3}, \mathrm{~F}^{-}$and $\mathrm{NO}_{3}{ }^{-}$as well as detailed investigation of the $\mathrm{pH}$ range 8.5 to 9.5 for the initial $\mathrm{NaCl}$ concentrations of $5 \mathrm{~g} / \mathrm{L}$ and $20 \mathrm{~g} / \mathrm{L}$ (results not shown). Data on hydrated ionic radii and hydration energy are outlined in Table 1. 
$\mathrm{Na}_{2} \mathrm{SO}_{4}(99 \%$ purity) was used in the electrode rinse solution (Fisher Scientific UK) and analytical grade reagents $\mathrm{NaOH}$ and $\mathrm{HCl}$ (Fisher Scientific UK) were used for $\mathrm{pH}$ adjustments and membrane cleaning.

Three different types of OM were selected for use in this study: humic acid sodium salt (HA), tannic acid (TA) and alginic acid sodium salt (AA) (all Sigma Aldrich UK). The concentration of $\mathrm{OM}$ in different waters is highly variable [15] and hence an average OM concentration of 12.5 $\mathrm{mgC} / \mathrm{L}$ was used in all experiments. The respective OM solutions were prepared by dissolving HA, TA and AA in ultrapure water and adding them to the feed solution. Physical and chemical properties of the OM compounds are outlined in Table 2.

[Table 2]

Major functional groups of HA include carboxylic, phenolic, alcohol/aldehyde acids, and methoxyl and HA is negatively charged at neutral $\mathrm{pH}$ [22]. As a polyphenol, TA can form inter- and intramolecular hydrogen bonds and often exists in solution as loosely bound complexes of molecules [23]. At acidic pH TA is neutrally charged, however as $\mathrm{pH}$ increases the charge becomes negative [24]. AA is a naturally occurring hydrophilic colloidal polysaccharide, is obtained from brown seaweed and exhibits negatively charged carboxylate and neutral hydroxyl groups at pH 7 [25]. Below $\mathrm{pH} 4$, the charge density decreases causing increased aggregation, whereas above $\mathrm{pH} 8$ dissociation has been observed [26].

\subsection{Electrodialysis System}

The ED stack used was a BEL-500 unit (Berghof, Germany) with seven Neosepta CMX-SB cationexchange membranes (CEMs) and six Neosepta AMX-SB anion-exchange membranes (AEMs) (supplied by Eurodia, Germany; manufactured by Astom Corporation, Tokyo, Japan) with an 
124 available membrane area of $58 \mathrm{~cm}^{2}$ each. The ED cell was connected to a DC electric potential 125 (GW Instek DC Power supply Model GPR-1810HD, Taiwan) through $\mathrm{TiO}_{2}$-coated titanium 126 electrodes. A schematic of the ED system is shown in Figure 1.

130 The limiting current density (LCD, $7.8 \mathrm{~mA} / \mathrm{cm}^{2}$ ) was derived from a set of current-voltage curves 131 measured in the ED cell and in consequence the applied voltage fixed to $10 \mathrm{~V}$ to operate below the 132 LCD. Diluate and concentrate were recirculated through the ED cell at a flow rate of $1.5 \mathrm{~L} / \mathrm{min}$ until 133 the desired product concentration $(0.5 \mathrm{~g} / \mathrm{L} \mathrm{NaCl})$ was achieved in the diluate. $0.5 \mathrm{~mol} / \mathrm{L} \mathrm{Na}_{2} \mathrm{SO}_{4}$ 134 was used as an electrode rinse solution at a flow rate of $1.5 \mathrm{~L} / \mathrm{min}$, in order to prevent the generation 135 of chlorine or hypochlorite, which could be hazardous for the electrodes, had $\mathrm{NaCl}$ been used 136 instead.

138 The resistance across the ED stack was calculated using Ohms law:

$$
R=\frac{E}{I}
$$

140 Where, $R$ is the resistance $(\mathrm{Ohm}), E$ the electrical potential (Volt) and $I$ the electrical current 141 (Ampere).

\subsection{Analytical Methods}

144 The $\mathrm{pH}$, electrical conductivity (EC) and temperature of samples taken from the diluate and concentrate during each experiment was measured using a pH/Conductivity meter (Multiline P4 combination pH electrode, WTW Germany).

$148 \mathrm{~F}^{-}$and $\mathrm{NO}_{3}{ }^{-}$concentrations were determined using ion-selective electrodes (ISE) in conjunction 149 with a standard reference electrode connected to a Metrohm 781 Ion Meter (UK). The ISEs were 
150

regularly calibrated, with and without $\mathrm{OM}$, and cleaned using standard methods. Standards and samples were mixed with a total ionic strength adjustment buffer (TISAB) to avoid possible interferences resulting from changes in solution $\mathrm{pH}$ and conductivity. $\mathrm{NO}_{3}{ }^{-}$sample analysis was checked using a Quickchem 8500 FIA Nutrient Analyser (Lachat Instruments, Colorado, USA) and $\mathrm{F}^{-}$analysis was verified using a DX-500 ion chromatograph (DIONEX, Sunnyvale, CA, USA). Sample concentrations were in agreement with ISE results. Total concentrations of $\mathrm{H}_{3} \mathrm{BO}_{3}$ were determined by ICP-OES using a Perkin Elmer Optima 5300DV instrument (Perkin Elmer, UK).

UV-Visible Spectrometry (Varian Cary 100 Scan, UK) was utilized to determine the absorbance of $\mathrm{OM}$ in experimental samples. HA was analyzed at a wavelength of $254 \mathrm{~nm}$, whereas TA and AA were analyzed at wavelengths of $275 \mathrm{~nm}$ and $198 \mathrm{~nm}$, respectively. Specific UV absorbance (SUVA, L/mg.m) values were calculated for HA as in equation (2):

$$
\mathrm{SUVA}=\frac{\mathrm{UV} \mathrm{Abs}(/ \mathrm{m})}{\mathrm{DOC}(\mathrm{mgC} / \mathrm{L})} \times 100
$$

Non-purgeable organic carbon (NPOC) concentrations were determined using a total organic carbon analyser (Shimadzu TOC-VCPH, UK).

The mass of contaminants deposited on the membranes was calculating using a mass balance:

$$
M_{\text {Dep }}=M_{\mathrm{F}}-M_{\mathrm{D}}-M_{\mathrm{C}}
$$

where $M_{\text {Dep }}$ is deposit, $M_{\mathrm{F}}$ feed, $M_{\mathrm{D}}$ diluate and $M_{\mathrm{C}}$ concentrate mass (mmol for $\mathrm{H}_{3} \mathrm{BO}_{3}, \mathrm{~F}^{-}, \mathrm{NO}_{3}{ }^{-}$), respectively.

\subsection{Experimental Protocol}

Concentrate and diluate $\mathrm{pH}$ was maintained constant during the experiments and adjusted by the addition of $1 \mathrm{~mol} / \mathrm{L} \mathrm{HCl}$ and/or $\mathrm{NaOH}$ in the range of $\mathrm{pH} \mathrm{3-12.} \mathrm{EC} \mathrm{of} \mathrm{both} \mathrm{solutions} \mathrm{was}$ continuously monitored and samples were collected at the beginning and at 20 minute intervals for 
analyses of $\mathrm{H}_{3} \mathrm{BO}_{3}, \mathrm{~F}^{-}, \mathrm{NO}_{3}{ }^{-}$, UV-Vis absorbance and non-purgeable organic carbon (NPOC). After the completion of each experiment, cleaning solutions of $0.1 \mathrm{~mol} / \mathrm{L} \mathrm{HCl}, 0.1 \mathrm{~mol} / \mathrm{L} \mathrm{NaOH}$ and ultrapure water were circulated through the ED cell for 20 minutes each in order to remove any deposits. Samples taken from the cleaning solutions were analysed for UV-Vis absorbance and NPOC. After each set of OM experiments, the ED cell was dismounted and photographs were taken of the anion- and cation-exchange membranes.

Ion and EC removal $\left(\mathrm{R}_{D}, \%\right)$ from the diluate was calculated using eqn (4):

$$
\mathrm{R}_{D}=\frac{\left(C_{D i}^{0}-C_{D i}^{T}\right)}{C_{D i}^{0}} \times 100 \%
$$

where, $C_{D i}^{0}$ is the initial diluate ion concentration or EC and $C_{D i}^{T}$ is the diluate ion concentration or EC in the time period $T$ (hours). Average ion and EC removal (\%) was calculated along with standard deviation $( \pm \%)$. Note that ion removal includes deposit formation, while the flux of ions and EC $\left(J_{i}, \mathrm{mmol} / \mathrm{m}^{2} . \mathrm{h}\right.$ for ions and $\mathrm{mS} / \mathrm{cm} / \mathrm{m}^{2} . \mathrm{h}$ for EC) across the membranes was calculated using eqn (5):

$$
J_{i}=\frac{\left(C_{C i}^{T}-C_{C i}^{0}\right)}{A_{m} T}
$$

where, $C_{C i}^{T}$ (mmol for $\mathrm{B}(\mathrm{OH})_{4}{ }^{-}, \mathrm{F}^{-}$and $\mathrm{NO}_{3}{ }^{-}, \mathrm{mS} / \mathrm{cm}$ for EC) is concentrate mass (ions) in the concentrate in the time period $T, C_{C i}^{0}$ is the initial mass within the concentrate and $A_{\mathrm{m}}$ is the membrane area $\left(\mathrm{m}^{2}\right)$ used in the transport of the respective ion.

\section{Results and Discussion}

\subsection{Inorganic trace contaminant removal}

As a first stage the removal of ions in the absence of OM was determined to establish a baseline. The removal of $\mathrm{F}^{-}$from the diluate is shown in Figure $2 \mathrm{~A}$. The removal of $\mathrm{F}^{-}$was independent of 
$199 \mathrm{pH}$, which is due to the $\mathrm{pH}$ independence of $\mathrm{F}^{-}$speciation [27]. $\mathrm{F}^{-}$ions removal was $65.6 \pm 12.0 \%$, 200 while $\mathrm{F}^{-}$flux was approximately $10 \mathrm{mmol} / \mathrm{m}^{2} \cdot \mathrm{h}$ (see Figure $3 \mathrm{~A}$ ).

[Figure 2]

Removal of $\mathrm{NO}_{3}{ }^{-}$is higher than that of $\mathrm{F}$ - but equally $\mathrm{pH}$ independent (Figure 2B), again because NO3- speciation does not vary over the $\mathrm{pH}$ range studied [28]. The average removal of NO3- was $94.1 \pm 1.3 \%$ while NO3- flux was significantly higher than for F- and decreased gradually from 830 to $408 \mathrm{mmol} / \mathrm{m} 2 . \mathrm{h}$ (Figure 3B).

$\mathrm{B}(\mathrm{OH})_{3}$ does not dissociate at $\mathrm{pH}$ 3-8 and in consequence is not transported effectively through the 212 AEM (see Figure 2C). Above $\mathrm{pH} 9$ removal increases to $61.2 \%$ at $\mathrm{pH} 12$ due to $\mathrm{B}(\mathrm{OH})_{3}$ 213 dissociation and speciation hence plays an important role. While Yazicigil et al. [13] determined 214 that $\mathrm{pH} 9$ was the optimal point for $\mathrm{B}(\mathrm{OH})_{4}{ }^{-}$removal, in this study it was only $13.7 \%$ at $\mathrm{pH} 9$. $215 \mathrm{~B}(\mathrm{OH})_{4}{ }^{-}$flux is in the same order of magnitude as F- but increased during experiments (see Figure 216 3C) which confirms the findings of Yazicigil et al. who attributed this to the increase in 217 electrochemical potentials gradient between the diluate and concentrate (i.e. larger difference in salt 218 concentration) [13]. The dissociation constant of $\mathrm{B}(\mathrm{OH})_{3}$ decreases with increasing $\mathrm{NaCl}$ 219 concentration [29]. Further ED experiments were undertaken to examine this effect with a solution $220 \mathrm{pH}$ range between 8.5 and 9.5 (insert Figure 2D) at two feed $\mathrm{NaCl}$ concentrations of 5 and $20 \mathrm{~g} / \mathrm{L}$ $221 \mathrm{NaCl}$. In the $5 \mathrm{~g} / \mathrm{L}$ experiment $\mathrm{B}(\mathrm{OH})_{4}{ }^{-}$removal ranged from $6.1 \%$ at $\mathrm{pH} 8.5$ to $29.4 \%$ at $\mathrm{pH} 9.5$. $222 \mathrm{~B}(\mathrm{OH})_{4}{ }^{-}$was not removed over this $\mathrm{pH}$ range in the $20 \mathrm{~g} / \mathrm{L}$ experiment presumably due to the higher concentration of competitive ions within the diluate. In consequence, no discernable shift in 
the dissociation constant of $\mathrm{B}(\mathrm{OH})_{3}$ was observed. The results demonstrate however that $\mathrm{NaCl}$ concentration affects removal of other ions.

The ionic characteristics (Table 1) can be used to explain differences in the transport (removal and flux) of $\mathrm{F}^{-}$and $\mathrm{NO}_{3}{ }^{-}$through the ion-exchange membranes. As no data was available on the hydrated radius of $\mathrm{B}(\mathrm{OH})_{4}{ }^{-}$, comparison of $\mathrm{B}(\mathrm{OH})_{4}{ }^{-}$removal and ionic characteristics is not discussed. Ions with smaller intrinsic crystal radii have higher hydration numbers, larger hydrated radii and hold their hydration shells more strongly [30], as illustrated in Figure 4. The crystal ionic radius of $\mathrm{F}^{-}$is $0.116 \mathrm{~nm}$ compared with $0.179 \mathrm{~nm}$ for $\mathrm{NO}_{3}{ }^{-}$. The larger the crystal ionic radius the more diffuse the electric charge and the fewer water molecules surround the ion [31]. Therefore, $\mathrm{NO}_{3}{ }^{-}$ions are less hydrated than $\mathrm{F}^{-}$ions may separate from its hydration layer [30] and transport through the ion-exchange membranes more easily.

The strength of hydration of $\mathrm{F}^{-}$and $\mathrm{NO}_{3}{ }^{-}$is quantified by the Gibbs energy of hydration and the number of water molecules within their hydration shells. $\mathrm{NO}_{3}{ }^{-}$has a lower Gibbs free energy (-275 $\mathrm{kJ} / \mathrm{mol}$ compared to $-345 \mathrm{~kJ} / \mathrm{mol}$ for $\mathrm{F}^{-}$). While it is to date not understood if water molecules separate from their ions during transport through ion-exchange membranes, it is hypothesised that separation is possible if the 'transport energy' is greater than the Gibbs free energy that bonds the hydrated shell to the ion.

Ion mobility ionic permeabilities [32] further influence transport through ion-exchange membranes.

247 The ionic mobility of $\mathrm{NO}_{3}{ }^{-}$in solution $\left(7.4 \times 10^{-8} \mathrm{~m}^{2} / \mathrm{sV}\right)$ solution is greater than the ionic mobility of $\mathrm{F}^{-}\left(5.7 \times 10^{-8} \mathrm{~m}^{2} / \mathrm{sV}\right)$ [33]. The current passing through an ionic solution in ED and the resultant transport of ions is related to the conductivity of the ionic solutions. The ion equivalent conductivity 
of $\mathrm{NO}_{3}^{-}\left(71.5 \mathrm{~cm}^{2} / \Omega\right.$.equiv) is also greater than that of $\mathrm{F}^{-}\left(55.4 \mathrm{~cm}^{2} / \Omega\right.$.equiv $)$, all factors 251 contributing to higher flux of $\mathrm{NO}_{3}^{-}$than $\mathrm{F}^{-}$. To confirm those results independent of their 252 concentration, an experiment with the same initial mass concentration for boron, $\mathrm{F}^{-}$and $\mathrm{NO}_{3}^{-}(10$ $253 \mathrm{mg} / \mathrm{L}$ at $\mathrm{pH}$ 10) was carried out. The removal of $\mathrm{NO}_{3}{ }^{-}$was $95.3 \%$ compared with $76.2 \%$ for $\mathrm{F}^{-}$, 254 further indicating that $\mathrm{NO}_{3}{ }^{-}$with the smaller hydrated radius is removed more efficiently than $\mathrm{F}^{-}$ 255 with the larger hydrated radius.

\subsection{Organic matter removal}

Figure 5 shows the removal of $\mathrm{OM}$ as a function of solution $\mathrm{pH}$ in diluate and concentrate. The fact that $\mathrm{OM}$ is removed from both compartments indicates that this removal is a deposition on the membrane rather than transport through the membrane. However, staining of the membranes

261 indicates that membrane penetration also occurs. Removal of AA from the diluate is low with an average of $9.2 \pm 1.6 \%$ and independent of $\mathrm{pH}$ given its negative charge at $\mathrm{pH} 3-12$. The removal of HA and TA from the diluate is higher with an average removal of $19.1 \pm 3.7 \%$ and $19.8 \pm 9.5 \%$, respectively. While HA removal is $\mathrm{pH}$ independent, the removal of TA increased with $\mathrm{pH}$ to $44.3 \%$ at $\mathrm{pH} 12$ due to its increasing negative charge. Removal of OM from the concentrate was less than from the diluate due to electrostatic repulsion with the negatively charged functional groups in the 267 CEMs adjacent to the concentrate compartment. This confirms the results of Park et al. who found that deposits occur mostly on the diluate side of AEM membranes.

[Figure 5]

\subsection{Effect of organic matter on inorganic trace contaminant removal}

273 Organic matter $(\mathrm{OM})$ deposits on the membranes and interacts with inorganic contaminants. The removal of $\mathrm{F}^{-}$was greater in the presence of $\mathrm{OM}$ (Figure 2A), which can be attributed to the binding of $\mathrm{F}^{-}$to the $\mathrm{OM}[16]$. The average percentage of $\mathrm{F}^{-}$ions removed with TA was $74.8 \pm 6.0 \%$, 
followed by AA and HA with $72.9 \pm 5.8 \%$ and $72.5 \pm 4.5 \%$ respectively. The flux of $\mathrm{F}^{-}$was 277 reduced in the presence of OM. The final flux (after 140 minutes) was $10.0 \mathrm{mmol} / \mathrm{m}^{2} . \mathrm{h}, 8.6$ $278 \mathrm{mmol} / \mathrm{m}^{2} . \mathrm{h}$ and $9.4 \mathrm{mmol} / \mathrm{m}^{2} . \mathrm{h}$ with HA, TA and AA, respectively compared to $10.7 \mathrm{mmol} / \mathrm{m}^{2} . \mathrm{h}$ in 279 the absence of OM. Combined increase in removal and reduced flux indicates $\mathrm{F}^{-}$membrane 280 deposition.

No significant difference in $\mathrm{NO}_{3}{ }^{-}$due to $\mathrm{OM}$; HA $(91.9 \pm 3.5 \%)$, TA $(91.4 \pm 4.9 \%)$ and AA $(92.6$ $283 \pm 0.8 \%$ ) removal was observed. For experiments with $\mathrm{TA}, \mathrm{NO}_{3}{ }^{-}$removal was highest under acidic284 neutral $\mathrm{pH}$ conditions $(95.2-93.2 \%$ at $\mathrm{pH} 3-7)$. In $\mathrm{HA}$ experiments, $\mathrm{NO}_{3}{ }^{-}$removal was $\mathrm{pH}$ 285 independent while the flux of $\mathrm{NO}_{3}{ }^{-}$(Figure 3B) was reduced in the presence of OM. This again 286 demonstrated some degree of membrane deposition.

The presence of OM also enhanced boron removal between $\mathrm{pH} 3$ and 8 (Figure 2C) while above $\mathrm{pH}$ 9, the removal of $\mathrm{B}(\mathrm{OH})_{4}{ }^{-}$in the presence of $\mathrm{OM}$ was lower. $\mathrm{B}(\mathrm{OH})_{4}{ }^{-}$flux at high $\mathrm{pH}$ was lower in the presence of $\mathrm{OM}$ (Figure $3 \mathrm{C}$ ), and again results indicate $\mathrm{B}(\mathrm{OH})_{4}{ }^{-}-\mathrm{OM}$ complexation and $\mathrm{B}(\mathrm{OH})_{4}{ }^{-}$membrane deposition.

\subsection{Inorganic trace contaminant membrane deposition}

The deposit formation can be quantified using mass balance. The mass of $\mathrm{F}^{-}$deposited on the membranes is shown in Figure 6A, with negligible deposition in experiments without OM. In the presence of OM the mass of $\mathrm{F}^{-}$deposited was between 0.1 and $0.6 \mathrm{mmol}$ (4.7 and $28.8 \%$ initial mass); with a greater amount deposited with HA and TA. HA contains voids which can trap inorganic compounds [34] and binding of $\mathrm{F}^{-}$has been shown to be $\mathrm{pH}$ dependent [16]. Hayes [16] studied the binding of $\mathrm{F}^{-}$to $\mathrm{HA}$ as a function of solution $\mathrm{pH}(5.0-6.6)$ and in this narrow $\mathrm{pH}$ range

$300 \mathrm{~F}^{-}$was being trapped within the large structure of HA rather than bound to a particular functional 301 group. As solution $\mathrm{pH}$ increases HA deprotonates and the negative charge on the carboxylates 
repels the $\mathrm{F}^{-}$ion. This phenomenon was not observed in this current study due to the fact that the adsorption of $\mathrm{F}^{-}$in $\mathrm{ED}$ would be governed by several other factors (e.g. presence of other contaminants).

The mass of $\mathrm{NO}_{3}{ }^{-}$deposited on the membranes was greater in experiments with $\mathrm{OM}$ (Figure 6B) with values of between 4.6 and $13.8 \mathrm{mmol}$ (8.1 and $24.2 \%$ initial mass). Contrary to the negative charge of $\mathrm{HA}$ above $\mathrm{pH} 5$ (Table 2) the mass of $\mathrm{NO}_{3}{ }^{-}$adsorbed to the membranes in the presence of HA increased above pH5. Adsorption of $\mathrm{NO}_{3}{ }^{-}$in experiments with TA was independent of $\mathrm{pH}$. In the presence of $\mathrm{AA}$, the mass of $\mathrm{NO}_{3}{ }^{-}$adsorbed was lower at $\mathrm{pH} 6-8$ because repulsion between the negatively charged $\mathrm{AA}$ and $\mathrm{NO}_{3}{ }^{-}$would be expected.

The mass of $\mathrm{B}(\mathrm{OH})_{4}{ }^{-}$deposited on the membranes is greater in experiments with $\mathrm{OM}$ (Figure 6C) with values of between 0.3 and $1.4 \mathrm{mmol}$ (4.0 and $19.0 \%$ initial mass). Removal of $\mathrm{B}(\mathrm{OH})_{3}$ between $\mathrm{pH} 3$ and 8 (Figure $2 \mathrm{C}$ ) may be the result of $\mathrm{B}(\mathrm{OH})_{3}$ complexation with polar organic compounds [35], such as HA. Schmitt-Kopplin et al. [36] postulated that $\mathrm{B}(\mathrm{OH})_{3}$ binds to carboxylate groups $\left(\mathrm{COO}^{-}\right)$within $\mathrm{HA}$ where it forms a transient hydrogen bonded structure with the HA. A schematic of this complexation mechanism is shown in Figure 7. Due to the transport direction of the negatively charged $\mathrm{HA}, \mathrm{B}(\mathrm{OH})_{4}{ }^{-}$is deposited on the AEMs.

\subsection{Organic matter membrane deposition}

UV-Vis and NPOC measurements showed a decrease in OM within the ED system over the duration of each experiment. The reduction of $\mathrm{OM}$ in both diluate and concentrate indicates that the $\mathrm{OM}$ is deposited. Figure 8 shows that the mass of $\mathrm{OM}(\mathrm{mgC})$ deposited on the AEMs was greater than the mass deposited on the CEMs, which confirms results Lee et al. [20]. The negatively 
charged HA deposits more readily on the positively charged AEMs in experiments with a higher solution $\mathrm{pH}$. However, Park et al. [37] showed that HA has a negative zeta potential in a wide $\mathrm{pH}$ range, so that it can foul AEMs in almost the entire $\mathrm{pH}$ range. In this study the amount of HA deposited on the AEMs showed a slight decrease with increasing solution $\mathrm{pH}$ (from $\mathrm{pH}$ 6) (Figure 8A) which cannot be explained by repulsive forces. The macromolecular structures of humic substances influences the properties and affinities of these materials [38]. According to Chen and Schnitzer [39], humic substances behave like uncharged (spherical) polymers at very low pH whereas at high $\mathrm{pH}$, they exhibit polyelectrolytic character of linear shape. Lee et al. [17] postulated that the fouling of an AEM is related more to the properties of the foulant (humate) than the electrostatic force between the foulant and the membrane.

Unlike HA, the mass of TA deposited on the AEM was $\mathrm{pH}$ independent (Figure 8B), with an exception (decrease) at neutral $\mathrm{pH}$. As large molecular weight organics have more difficulty in permeating the AEMs [37], TA, with its lower molecular weight, has increased potential for transportation through the AEM compared to HA.

The mass of AA deposited on the AEMs was lower than HA and TA over the studied pH range 347 (Figure 8C). Avaltroni et al. [26] found that the structure of AA follows three pH dependent trends 348 (1) increased aggregation below $\mathrm{pH} 4$ due to a decrease in charge density, (2) molecular expansion 349 between $\mathrm{pH} 4$ and 8 and (3) dissociation above $\mathrm{pH}$. The variability seen in the mass above $\mathrm{pH} 8$ could be attributed to AA dissociation.

The AEM surface in contact with the diluate showed visible fouling with HA and TA. This fouling 353 was not reversed by chemical cleaning indicative of strong binding of the OM to the AEM 
354 functional groups and penetration into the membrane. The observed colour change was more 355 pronounced on the area of membranes in contact with ED cell inlets. The fouling of the AEMs was 356 also accompanied by visible swelling. The hydrophobic and hydrophilic acids contained in OM 357 cannot pass through the membranes due to their high molecular weight and it is thought that a 358 fraction of the $\mathrm{OM}$ is transported through the membranes as a result of their negative charge density 359 and molecular structure $[17,18]$. The surface of the CEMs in contact with both the concentrate and 360 diluate presented little visible evidence of fouling, due to electrostatic repulsion of the negatively 361 charged functional groups within the CEM.

363 SUVA (L/mg.m) values for HA experiments are shown in Figure 8D. SUVA is used as an indicator 364 for the aromatic content of carbon within a water sample [40]. SUVA values in the diluate and 365 concentrate for the HA experiments were $\mathrm{pH}$ and time independent with a values between 2.6 and $3665.6 \mathrm{~L} / \mathrm{mg} . \mathrm{m}$. Shin et al. [41] stated that the non-aromatic (aliphatic nature) fractions of HA have a 367 larger molecular size in comparison to the aromatic and carboxylate groups of smaller size 368 fractions. Results from this study, therefore, indicate that ED does not separate the aromatic and 369 non-aromatic fractions of HA.

\subsection{ED parameters and performance}

372 An increase in ED stack resistance (see Eqn (2)) was observed at the beginning of the ED process in 373 all experiments as a result of ion depletion within the diluate and membrane boundary layer. An 374 increase in resistance observed at the end of the ED experiments without $\mathrm{OM}$ is attributed to the 375 higher demineralization rate in the diluate solution. ED stack resistance as a function of solution $\mathrm{pH}$ 376 is shown in Figure 9. 
The deposition of inorganic trace contaminants and OM on the membranes has implications for ED

381 performance. OM deposition as a foulant layer on and/or inside the membranes increases the 382 resistance at the membrane surface $[19,42]$. Between $\mathrm{pH} 3$ and 8 the average stack resistances were 383 indeed greater in the presence of OM; HA $(46.3 \pm 2.2 \Omega)$, TA $(51.3 \pm 5.0 \Omega)$ and AA $(44.5 \pm 1.6$ $384 \Omega$ ), due to enhanced $\mathrm{OM}$ deposition within this $\mathrm{pH}$ range (Figure 8). Above $\mathrm{pH} 8$, resistance 385 decreased due to decreased OM membrane deposition.

The performance of the ED process can also be evaluated by the removal of EC (Figure 2D). The average percentage of EC removed without OM was $93.0 \pm 2.1 \%$ compared with $91.7 \pm 2.5 \%$, $92.6 \pm 3.0 \%$ and $89.4 \pm 4.8 \%$ with HA, TA and AA respectively. The presence of OM on the membranes did not significantly lower EC removal. It is possible the OM was loosely packed on the AEM still allowing for the migration of salt ions through the membrane; though at a slightly decreased initial flux (Figure 4D).

\section{Conclusions}

The purpose of this study was to understand the impact of OM on inorganic contaminant removal. The removal of the contaminants followed the order $\mathrm{NO}_{3}{ }^{-}>\mathrm{F}^{-}>\mathrm{B}(\mathrm{OH})_{4}{ }^{-}$. The hydrated radius and subsequent strength of hydration shells is a parameter that plays a significant role in the transport of the ions during $\mathrm{ED}$; as $\mathrm{NO}_{3}{ }^{-}$with a smaller hydrated ionic radii and subsequent weaker hydration shell was removed more effectively than $\mathrm{F}^{-}$with a larger hydrated ionic radii and stronger hydration shell. The transport of $\mathrm{B}(\mathrm{OH})_{4}{ }^{-}$in $\mathrm{ED}$ was solution $\mathrm{pH}$ and hence speciation dependent with 401 increased removal at high $\mathrm{pH}$.

The removal of the inorganic contaminants was enhanced by the presence of OM while the flux decreased indicating mutual dependence of inorganic and organic contaminants in ED. The 
406

\section{Acknowledgements}

This work was initially funded through the Australian Research Council (ARC) Linkage Project LP0454254 in collaboration with Brisbane Water along with the ARC Discovery Project DP0559878. The authors thank Eurodia (Germany and France) for the provision of membranes for this project and Berghof (Germany) for the donation of the ED stack. Wytze Meindersma (Eindhoven University of Technology, Netherlands) and Bart van der Bruggen (University of Leuven, Belgium) are acknowledged for helpful discussions. Steffen Zuleeg (EAWAG, Switzerland) and Johannes Fritsch (University of Applied Sciences, Ravensburg-Weingarten, Germany) for help with limiting current density issues. The authors also thank Peter Anderson and Alan Simm (University of Edinburgh, UK) for boron analysis and discussions on boron chemistry and laboratory support, respectively.

\section{References}

[1] WHO, Guidelines for Drinking Water Quality, World Health Organization, 2006.

[2] R. Abu, K. Alsokhny, Geochemical assessment of groundwater contamination with special emphasis on fluoride concentration, North Jordan, Chemie der Erde - Geochem. 64 (2004) 171.

[3] N. Tamer, B.K. Köroğlu, C. Arslan, M. Akdoğan, M. Köroğlu, H. Çam, M. Yildiz, Osteosclerosis due to endemic fluorosis, Sci. Total Environ. 373 (2007) 43. 
432 [5] A. Elmidaoui, F. Elhannouni, M. Taky, L. Chay, M.A. Menkouchi Sahli, L. Echihabi, M. Hafsi, Optimization of nitrate removal operation from ground water by electrodialysis, Sep. Purif. Technol. 29 (2002) 235.

Council Directive 98/83/EC of 3 November 1998 on the quality of water intended for human consumption, Official Journal L 330, European Union, 1998, pp. 32-54.

[7] NHMRC, Australian Drinking Water Guidelines, National Health and Medical Research Council, Canberra, 2004.

[8] K. Kesore, F. Janowski, V.A. Shaposhnik, Highly effective electrodialysis for selective elimination of nitrates from drinking water, J. Membr. Sci. 127 (1997) 17.

J.M. Ortiz, J.A. Sotoca, E. Exposito, F. Gallud, V. Garcia-Garcia, V. Montiel, A. Aldaz, Brackish water desalination by electrodialysis: batch recirculation operation modeling, J. Membr. Sci. 252 (2005) 65.

[10] M. Turek, P. Dydo, J. Trojanowska, B. Bandura, Electrodialytic treatment of boroncontaining wastewater, Desalination. 205 (2007) 185.

[12] L. Melnik, O. Vysotskaja, B. Kornilovich, Boron behavior during desalination of sea and

[13] Z. Yazicigil, Y. Oztekin, Boron removal by electrodialysis with anion-exchange membranes, Desalination. 190 (2006) 71.

[14] J.A. Dean, Lange's handbook of chemistry, McGraw-Hill, New York, 1999.

[15] F.H. Frimmel, Characterization of natural organic matter as major constituents in aquatic

[16] D. Hayes, J. Carter, T.J. Manning, Fluoride binding to humic acid, J. Radioanal. Nucl. Chem. Lett. 201 (1995) 135. 
[17] H.J. Lee, D.H. Kim, J. Cho, S.H. Moon, Characterization of anion exchange membranes with natural organic matter (NOM) during electrodialysis, Desalination. 151 (2002) 43.

[18] D.H. Kim, S.H. Moon, J. Cho, Investigation of the adsorption and transport of natural organic matter (NOM) in ion-exchange membranes, Desalination. 151 (2002) 11.

[19] J.S. Park, J.H. Choi, K.H. Yeon, S.H. Moon, An approach to fouling characterization of an ion-exchange membrane using current-voltage relation and electrical impedance

[20] H.J. Lee, J.H. Choi, J. Cho, S.H. Moon, Characterization of anion exchange membranes 465

[21] A. Koparal, U. Ogutveren, Removal of nitrate from water by electroreduction and 467

[23] T. Shutava, M. Prouty, pH responsive decomposable layer-by-layer nanofilms and capsules

[24] J.H. An, S. Dultz, Adsorption of tannic acid on chitosan-montmorillonite as a function of $\mathrm{pH}$ and surface charge properties, Appl. Clay Sci. 36 (2007) 256.

[25] T. Coradin, J. Livage, Synthesis and characterization of alginate/silica biocomposites, J. SolGel Sci. Technol. 26 (2003) 1165.

[26] F. Avaltroni, M. Seijo, S. Ulrich, S. Stoll, K.J. Wilkinson, Conformational Changes and Aggregation of Alginic Acid as Determined By Fluorescence Correlation Spectroscopy, Biomacromolecules. 8 (2007) 106.

[27] L.A. Richards, B.S. Richards, H.M.A. Rossiter, A.I. Schäfer, Impact of speciation on fluoride, arsenic and magnesium retention by nanofiltration/reverse osmosis in remote australian communities, Desalination. Accepted (2009). 
482 [28] L.A. Richards, B.S. Richards, H.M.A. Rossiter, A.I. Schäfer, Impact of speciation on fluoride, arsenic and magnesium retention by nanofiltration/reverse osmosis in remote australian communities, Desalination. In press (2008).

[29] B.B. Owen, E.J. King, The Effect of Sodium Chloride upon the Ionization of Boric Acid at 486 Various Temperatures, J. Amer. Chem. Soc. 65 (1943) 1612.

[31] A.G. Volkov, S. Paula, D.W. Deamer, Two mechanisms of permeation of small neutral

[32] H. Strathmann, Ion-exchange membrane separation processes, Elsevier, Amsterdam, Netherlands, 2004.

[33] P.W. Atkins, Physical chemistry, Oxford University Press, Oxford, 1990.

[34] H.R. Schulten, M. Schnitzer, Three-dimensional models for humic acids and soil organic matter, Naturwissenschaften. 82 (1995) 487.

[35] E. Chauveheid, M. Denis, The boron-organic carbon correlation in water, Water Research. 38 (2004) 1663-1668.

[36] P. Schmitt-Kopplin, N. Hertkorn, A.W. Garrison, D. Freitag, A. Kettrup, Influence of Borate Buffers on the Electrophoretic Behavior of Humic Substances in Capillary Zone Electrophoresis, Anal. Chem. 70 (1998) 3798.

[37] J.S. Park, H.J. Lee, S.J.G. Choi, K.E., J. Cho, S.H. Moon, Fouling mitigation of anion exchange membrane by zeta potential control, J. Colloid Interface Sci. 259 (2003) 293.

[38] K. Ghosh, M. Schnitzer, Macromolecular structures of humic substances, Soil Science. 129 (1980) 266. 
[39] Y. Chen, M. Schnitzer, Viscosity measurements on soil humic substances, Soil Sci. Soc. Am. J. 40 (1976) 866.

[40] J.P. Croué, D. Violleau, C. Bodaire, B. Legube, Removal of hydrophobic and hydrophilic constituents by anion exchange resin, Water Sci. Technol. 40 (1999) 207.

[41] H.S. Shin, J.M. Monsallier, G.R. Choppin, Spectroscopic and chemical characterizations of molecular size fractionated humic acid, Talanta. 50 (1999) 641.

[42] V. Lindstrand, G. Sundstrom, A.S. Jonsson, Fouling of electrodialysis membranes by organic substances, Desalination. 128 (2000) 91.

[43] M.Y. Kiriukhin, K.D. Collins, Dynamic hydration numbers for biological important ions, Biophys. Chem. 99 (2002) 155.

[44] K.D. Collins, Sticky ions in biological systems, Proc. Natl. Acad. Sci. US. 92 (1995) 5553.

[45] L. Pauling, The nature of the chemical bond and the structure of molecules and crystals: An introduction to modern structural chemistry, Cornell University Press, New York, 1960.

[46] H. Corti, R. Crovetto, R. Fernandez-Prini, Mobilities and ion-pairing in $\mathrm{LiB}(\mathrm{OH})_{4}$ and $\mathrm{NaB}(\mathrm{OH})_{4}$ aqueous solutions. A conductivity study, J. Sol. Chem. 9 (1980) 617.

[47] Y. Marcus, Thermodynamics of solvation of ions Part 5.- Gibbs free energy of hydration at 298.15 K, J. Chem. Soc. Faraday Trans. 87 (1991) 2995.

[48] R.A. Robinson, R.H. Stokes, Electrolyte solutions, Butterworths, London, 1970.

[49] Y.P. Chin, G. Aiken, K.M. Danielsen, Binding of pyrene to aquatic and commercial humic substances: The role of molecular weight and aromaticity, Environ. Sci. Technol. 31 (1997) 1630.

[50] M. Fukushima, S. Tanaka, H. Nakamura, S. Ito, Acid-base characterization of molecular weight fractionated humic acid, Talanta. 43 (1996) 383.

[51] G.R. Choppin, P.M. Shanbhag, Binding of calcium by humic acid, J. Inorg. Nucl. Chem. 43 (1981) 921. 
533 [52] M. Terashima, M. Fukushima, S. Tanaka, Influence of $\mathrm{pH}$ on the surface activity of humic acid: micelle-like aggregate formation and interfacial adsorption, Colloids Surf., A. 247 (2004) 77.

536 [53] H.R. Schulten, A chemical structure for Humic Acid. Pyrolysis-gas chromatography/mass spectrometry and pyrolysis-soft ionization mass spectrometry evidence, in: N. Senesi, T.M. Miano, (Eds), Humic substances in the global environment and implications on human health, Elsevier Science, 1994, pp. 43-56. 


\section{$542 \quad$ List of Tables}

543

544 Table 1: Characteristics of the ions.

545

546 Table 2: Physical and chemical properties of organic matter (OM). 
547 Table 1

\begin{tabular}{|c|c|c|c|c|c|c|c|}
\hline Parameter & Unit & $\mathrm{Na}^{+}$ & $\mathrm{Cl}^{-}$ & $\mathbf{F}^{-}$ & $\mathrm{NO}_{3}^{-}$ & $\mathrm{B}(\mathrm{OH})_{4}$ & References \\
\hline \multirow[b]{2}{*}{ Crystal ionic radii, $r$} & \multirow[b]{2}{*}{$\mathrm{nm}$} & - & - & $0.116-0.119$ & $0.179-0.189$ & $0.244-0.261$ & {$[30,31,43-46]$} \\
\hline & & 0.117 & 0.164 & $0.133-0.135$ & 0.206 & & {$[45,47]$} \\
\hline Hydrated ionic radii, $\Delta r$ & $\mathrm{~nm}$ & 0.358 & 0.332 & 0.352 & 0.340 & $\mathrm{a}$ & [31] \\
\hline $\begin{array}{l}\text { Number of water molecules in } \\
\text { hydration shell, } n\end{array}$ & - & 3.5 & 2.0 & 2.7 & 2.0 & $\mathrm{a}$ & [47] \\
\hline $\begin{array}{l}\text { Molar Gibbs energy of } \\
\text { hydration, } \Delta_{\text {hyd }} G_{\text {calc }}^{*}\end{array}$ & $\mathrm{~kJ} / \mathrm{mol}$ & -385 & -270 & -345 & -275 & $\mathrm{a}$ & [47] \\
\hline Ion mobility at $25^{\circ} \mathrm{C}, u$ & $\mathrm{~m}^{2} / \mathrm{sV}$ & 5.19 & 7.91 & 5.70 & 7.40 & a & [33] \\
\hline $\begin{array}{c}\text { Ion equivalent conductivity, } \\
\lambda^{\circ} \text { equiv }\end{array}$ & $\mathrm{cm}^{2} / \Omega$ equiv & 50.1 & 76.4 & 55.4 & 71.5 & $\mathrm{a}$ & [48] \\
\hline
\end{tabular}

$548 \quad{ }^{a}$ Data not available. 


\begin{tabular}{|c|c|c|c|c|c|c|c|c|c|c|}
\hline $\begin{array}{l}\text { Organic } \\
\text { Type }\end{array}$ & Category & Origin & $\begin{array}{l}\text { Molecular } \\
\text { Formulae }\end{array}$ & $\begin{array}{c}\text { MW } \\
(\mathrm{g} / \mathrm{mol})\end{array}$ & $\begin{array}{c}\text { Carbon } \\
(\%)\end{array}$ & $\mathbf{p K a}$ & $\begin{array}{c}\text { Acidic } \\
\text { pH }\end{array}$ & $\begin{array}{c}\text { Charge } \\
\text { Neutral } \\
\text { pH }\end{array}$ & $\begin{array}{c}\text { Basic } \\
\text { pH }\end{array}$ & References \\
\hline $\begin{array}{l}\text { Humic } \\
\text { Acid } \\
\text { (HA) }\end{array}$ & OM surrogate & Soil & $\mathrm{C}_{342} \mathrm{H}_{388} \mathrm{O}_{124} \mathrm{~N}_{5}{ }^{\mathrm{a}}$ & 4100 & 56 & $3.5-5.04$ & Neutral & Negative & Negative & $\begin{array}{c}{[22,34,41,49-} \\
52]\end{array}$ \\
\hline $\begin{array}{l}\text { Tannic } \\
\text { Acid } \\
\text { (TA) }\end{array}$ & Polyphenol & Plants & $\mathrm{C}_{76} \mathrm{H}_{52} \mathrm{O}_{46}$ & 1701 & 54 & $2.5-10$ & Neutral & Negative & Negative & [23] \\
\hline $\begin{array}{c}\text { Alginic } \\
\text { Acid } \\
\text { (AA) }\end{array}$ & Polysaccharide & $\begin{array}{c}\text { Brown } \\
\text { seaweed } \\
\text { and algae }\end{array}$ & {$\left[\mathrm{C}_{6} \mathrm{H}_{8} \mathrm{O}_{6}\right]_{\mathrm{n}}$} & 21000 & 36 & $2.0-3.5$ & Negative & Negative & Negative & [26] \\
\hline
\end{tabular}

$550 \quad$ a Based on model by [53]. ${ }^{\mathrm{b}}$ Sigma Aldrich Humic Acid. 
Figure 1. Schematic of the ED system used in this study

Figure 2. The removal of (A) $\mathrm{F}^{-}$, (B) $\mathrm{NO}_{3}{ }^{-}$, (C) $\mathrm{H}_{3} \mathrm{BO}_{3}$ and (D) $\mathrm{EC}$ (\%) from the diluate as a function of solution $\mathrm{pH}$ (Initial concentrations $5 \mathrm{mg} / \mathrm{L}\left(\mathrm{F}^{-}\right), 100 \mathrm{mg} / \mathrm{L}\left(\mathrm{NO}_{3}{ }^{-}\right), 10 \mathrm{mg} / \mathrm{L}\left(\mathrm{H}_{3} \mathrm{BO}_{3}\right), 5$ $\mathrm{g} / \mathrm{L} \mathrm{NaCl}$; experiment duration $140 \mathrm{~min}$ for each $\mathrm{pH}$ value).

558

Figure 3. Flux of (A) $\mathrm{F}^{-}(\mathrm{B}) \mathrm{NO}_{3}{ }^{-},(\mathrm{C}) \mathrm{B}(\mathrm{OH})_{4}{ }^{-}$and (D) $\mathrm{EC}$ (Initial mass $2.1 \mathrm{mmol}\left(\mathrm{F}^{-}\right), 57 \mathrm{mmol}$ 560 $\left(\mathrm{NO}_{3}{ }^{-}\right), 7.4 \mathrm{mmol}\left(\mathrm{H}_{3} \mathrm{BO}_{3}\right)$ (diluate and concentrate combined)).

Figure 4. Schematic representation of hydration shells around $\mathrm{F}^{-}$and $\mathrm{NO}_{3}{ }^{-}$ions (adapted from 563 [35]).

Figure 5. Organic matter $(\mathrm{OM})$ removal as a function of solution $\mathrm{pH}$ (Initial OM concentration 12.5 566 $\mathrm{mgC} / \mathrm{L})$.

Figure 6. Membrane deposit of (A) $\mathrm{F}^{-}$

(B) $\mathrm{NO}_{3}{ }^{-}$and $(\mathrm{C}) \mathrm{B}(\mathrm{OH})_{4}{ }^{-}$as a function of $\mathrm{pH}$. (Initial mass 569 $2.1 \mathrm{mmol}\left(\mathrm{F}^{-}\right), 57 \mathrm{mmol}\left(\mathrm{NO}_{3}{ }^{-}\right), 7.4 \mathrm{mmol}\left(\mathrm{H}_{3} \mathrm{BO}_{3}\right)$ (diluate and concentrate combined)).

Figure 7. Schematic of $\mathrm{B}(\mathrm{OH})_{3}$ complexation with humic substances.

Figure 8: Membrane deposit of (A) Humic, (B) Tannic and (C) Alginic acids and (D) SUVA (L/mg.m) for HA as a function of $\mathrm{pH}$ (Initial mass of OM $100 \mathrm{mgC}$ ).

Figure 9. ED stack resistance as a function of solution $\mathrm{pH}$. 
$577 \quad$ Figure 1

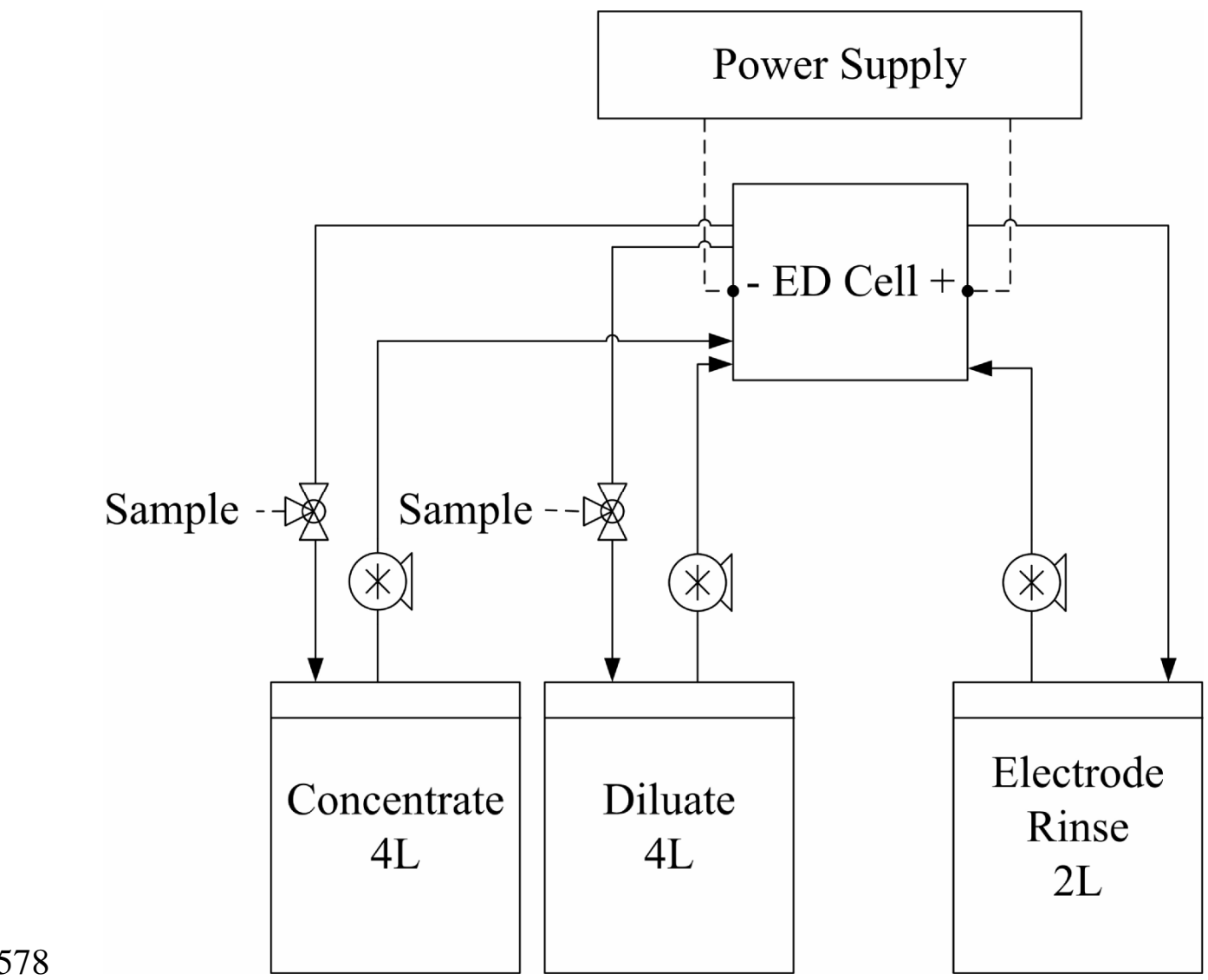


Figure 2

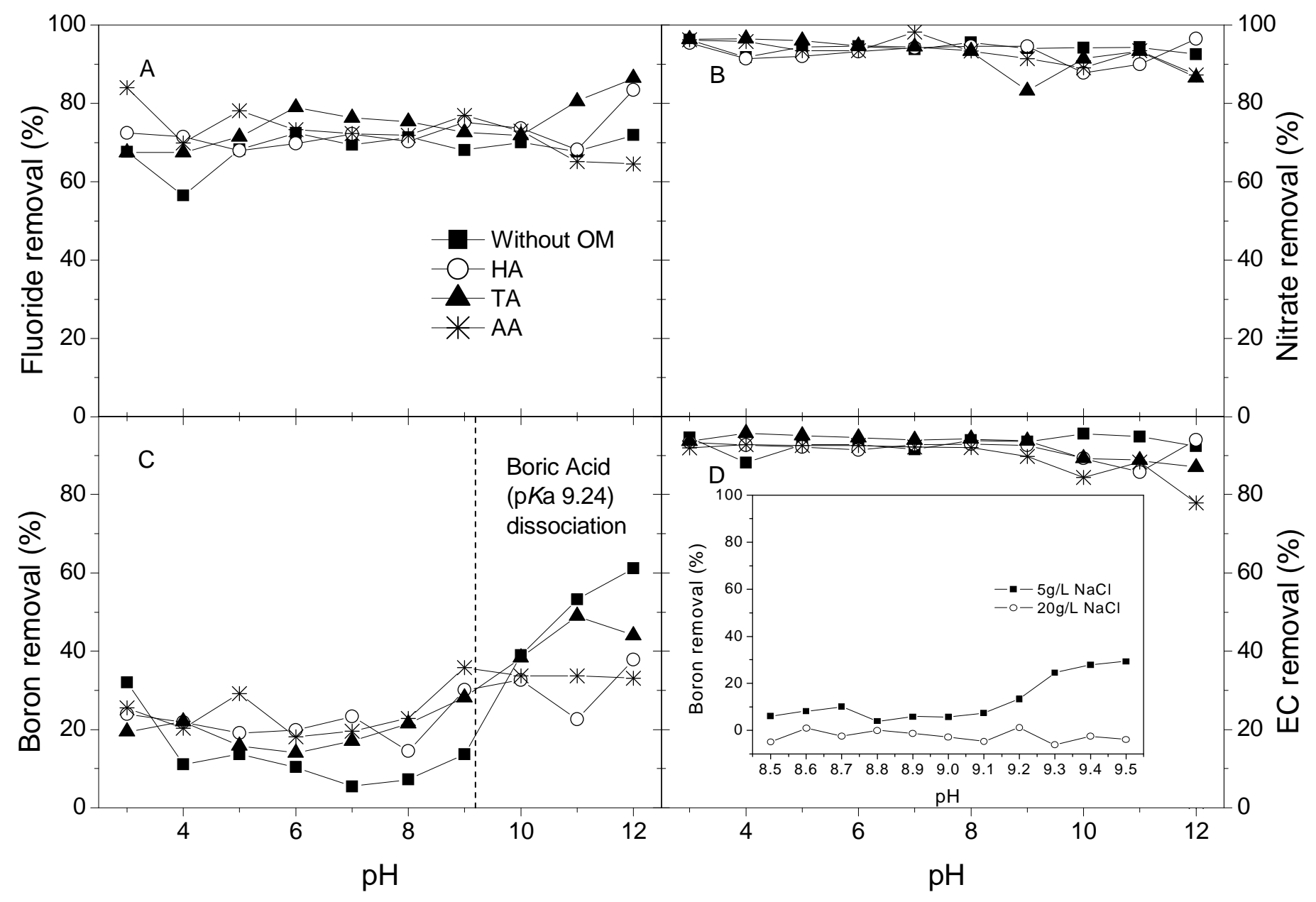


$581 \quad$ Figure 3

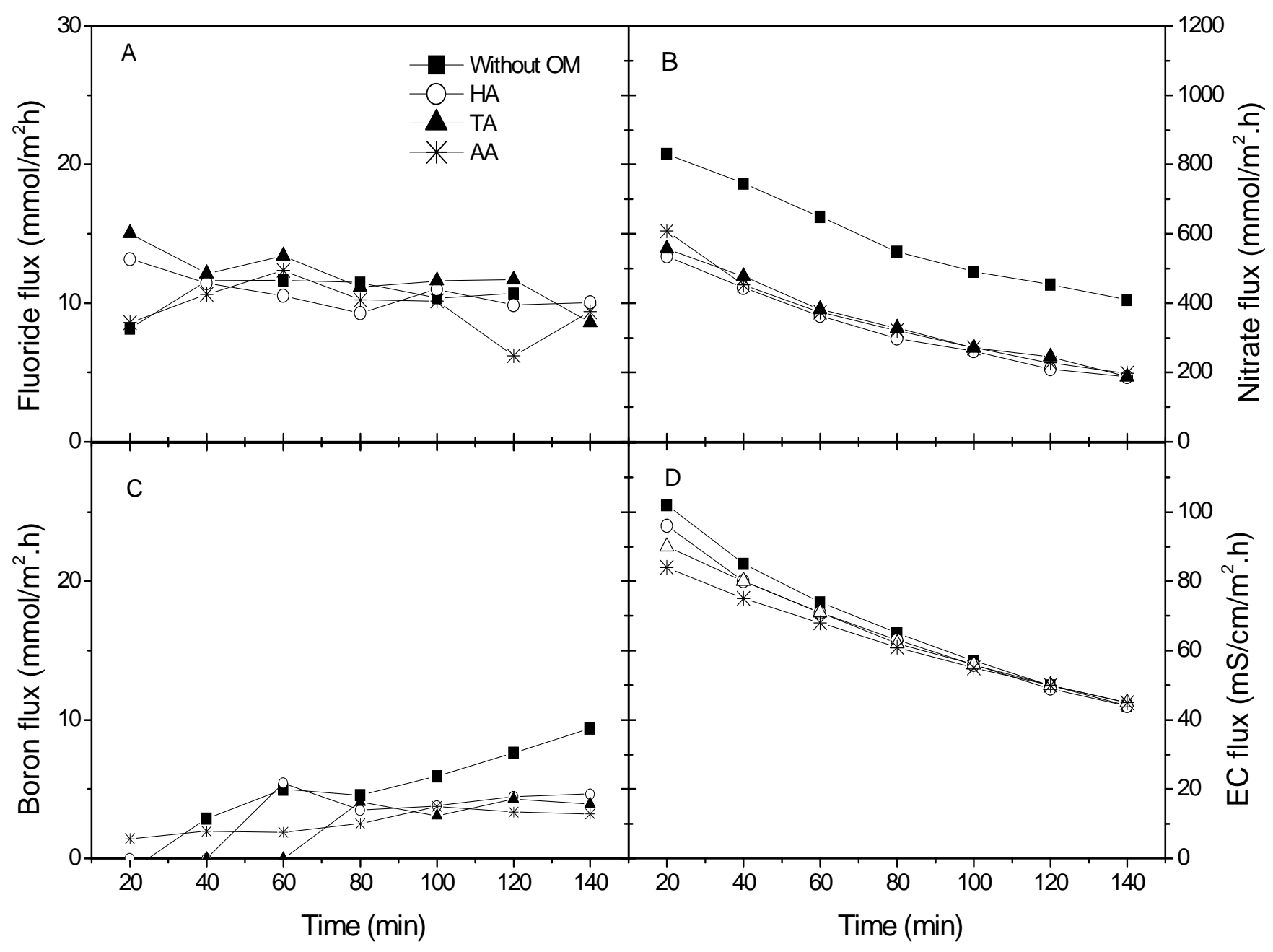

582 


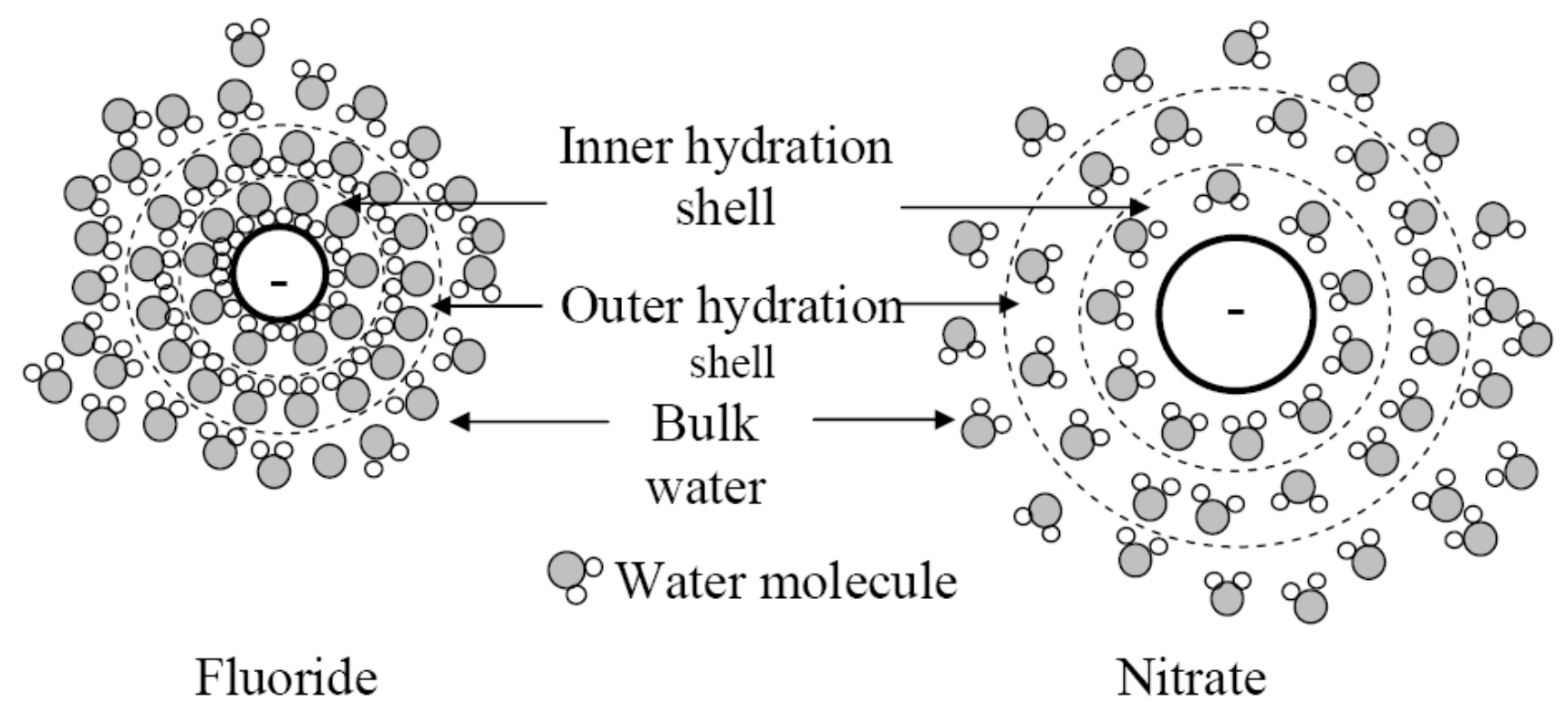


$585 \quad$ Figure 5

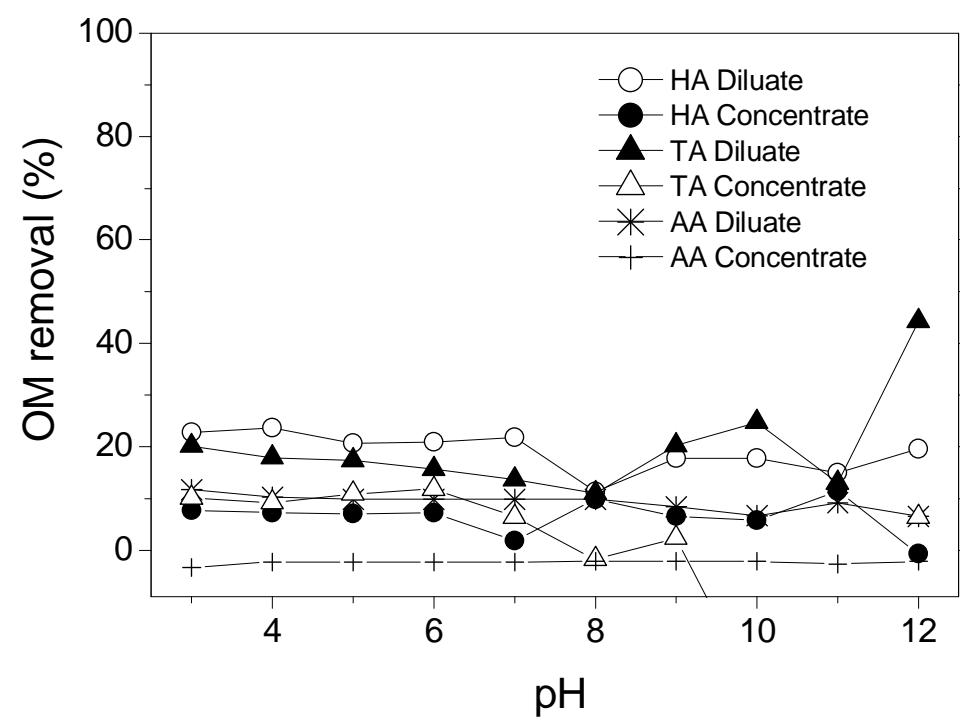

586 
Figure 6

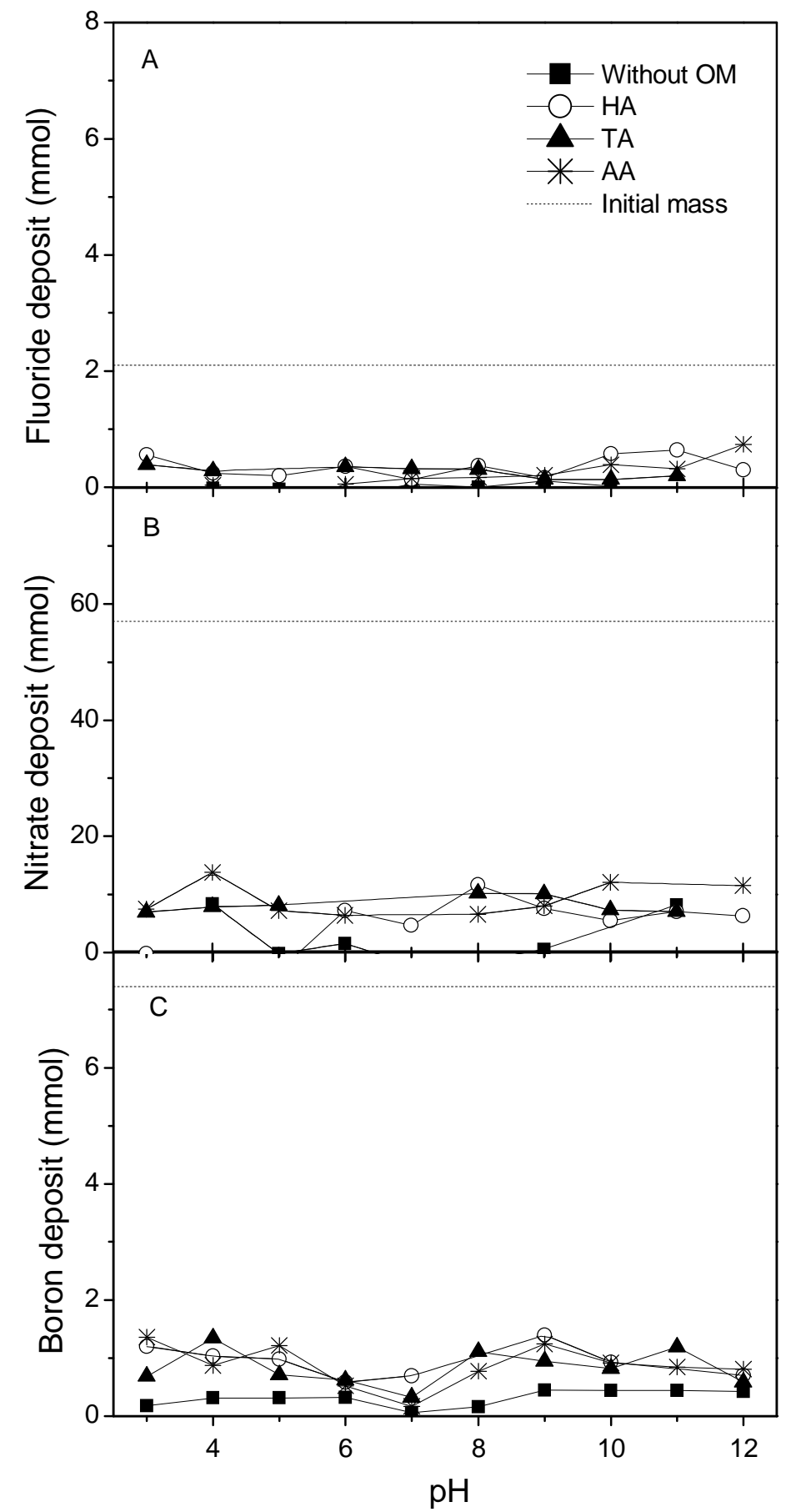

588 
$589 \quad$ Figure 7

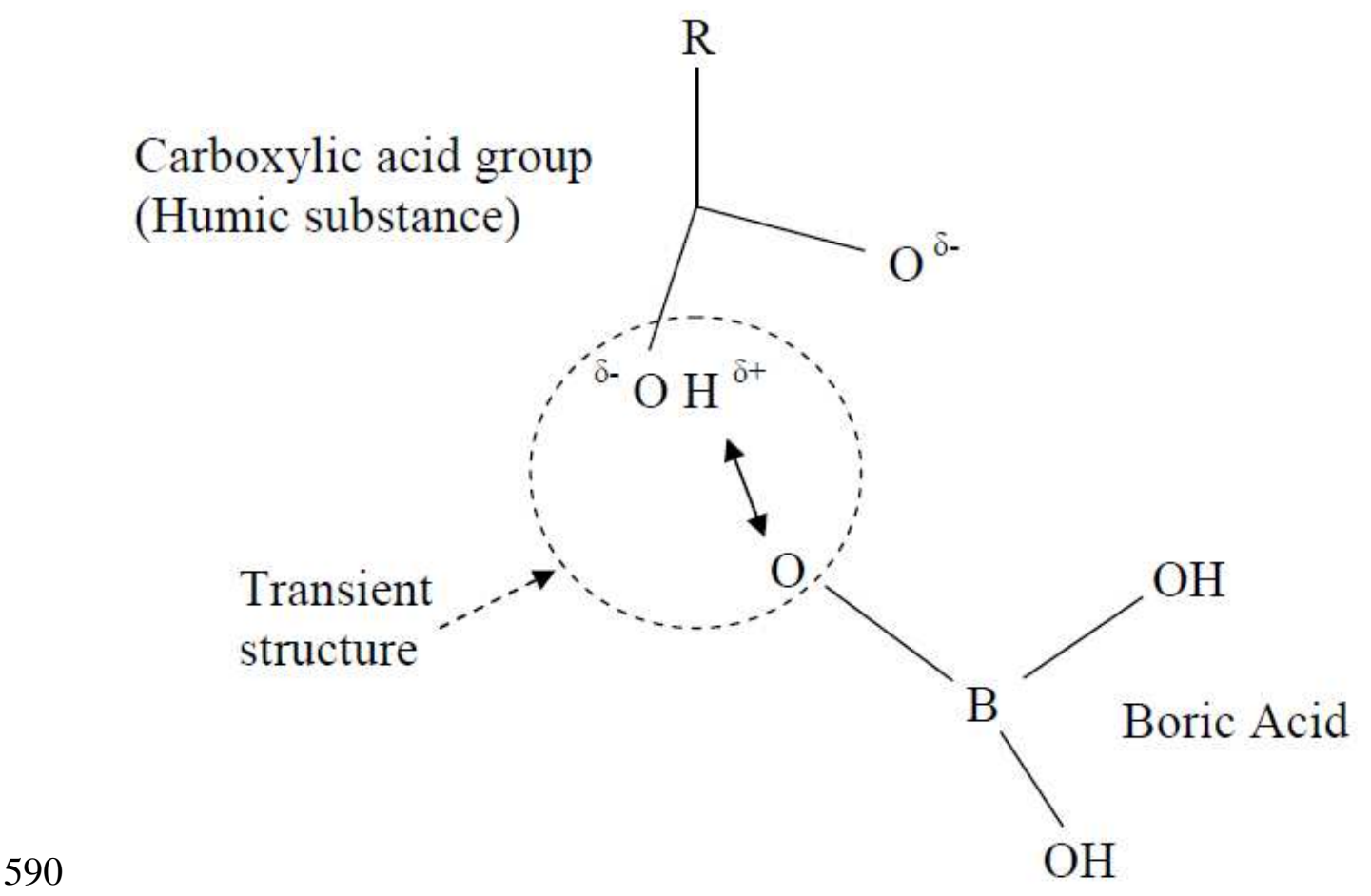


$591 \quad$ Figure 8

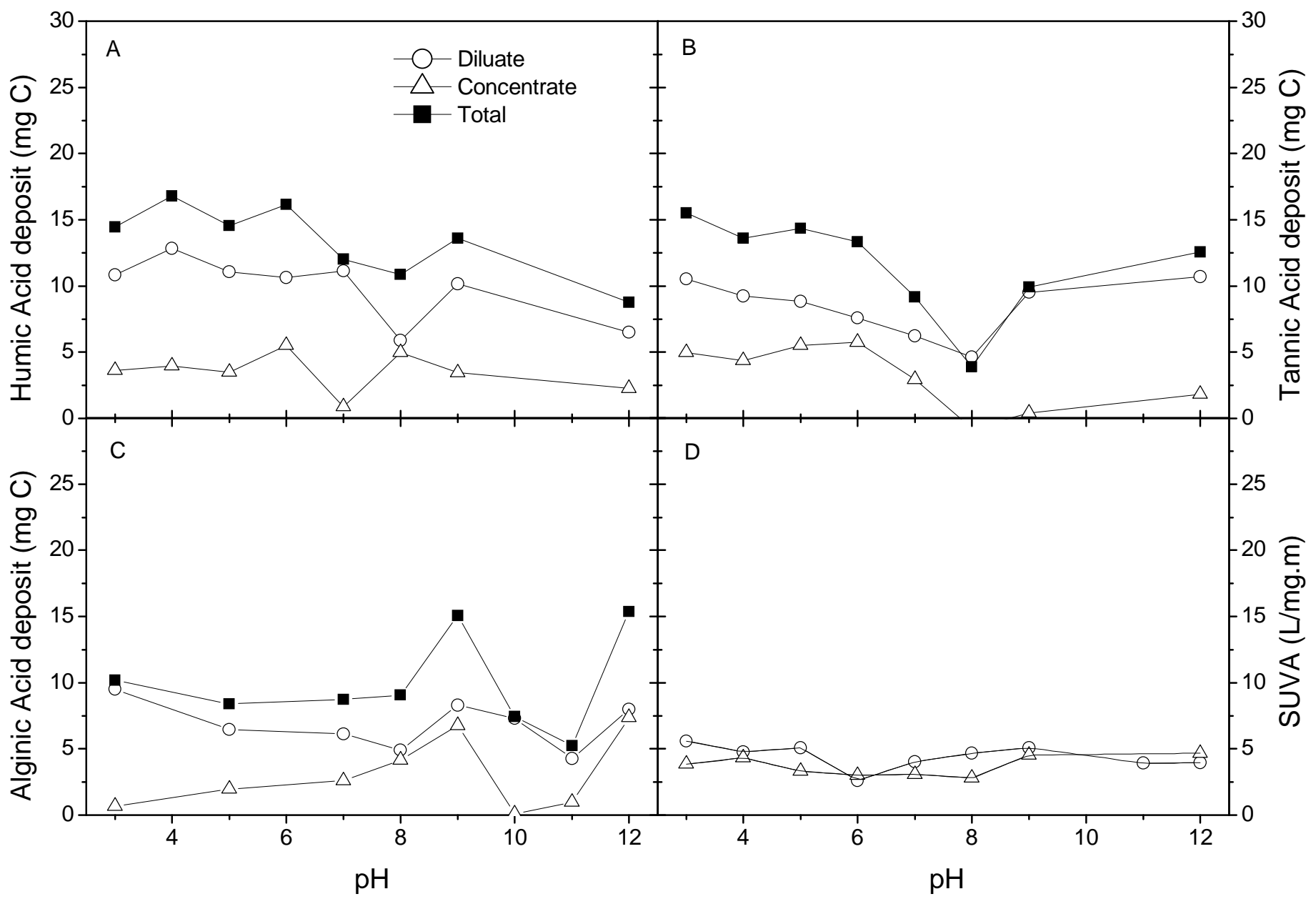

592 
$593 \quad$ Figure 9

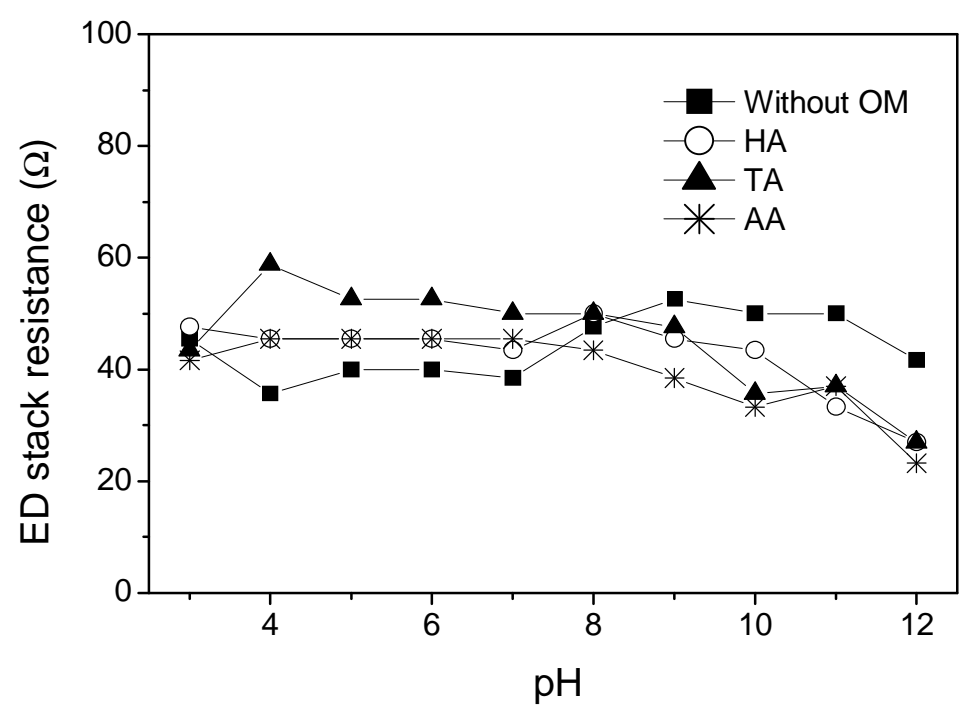

594 